To cite this article (example in APA citation format):

Jiménez Rivero, A., De Guzmán Báez, A., \& García Navarro, J. (2014). New composite gypsum plaster Ground waste rubber coming from pipe foam insulation. Construction and Building Materials, 55(2014), 146-152. https://doi.org/10.1016/j.conbuildmat.2014.01.027

\title{
New composite Gypsum Plaster - Ground Waste Rubber coming from Pipe Foam Insulation
}

\author{
Ana Jiménez Rivero*, Ana de Guzmán Báez, Justo García Navarro. \\ Grupo de Investigación Sostenibilidad en la Construcción y la Industria giSCI - UPM. \\ Departamento de Construcción y Vías Rurales, Escuela Técnica Superior de Ingenieros Agrónomos, Universidad \\ Politécnica de Madrid, Ciudad Universitaria s/n, 28040 Madrid, España.

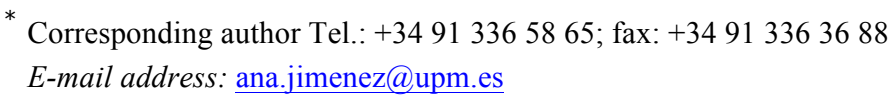

\begin{abstract}
Industrial production of pipe foam insulation generates huge volumes of scrap material, driving to a serious environmental problem.

This research studies the potential of adding different size particle proportions of this waste rubber to a plaster matrix. For this purpose, an experimental plan has been elaborated which characterizes the physical and mechanical behavior of the new composite: Shore $\mathrm{C}$ hardness, flexure and compressive strength. Furthermore, different particle sizes, weight rates and water/plaster ratios have been analyzed.

In view of the results this waste rubber could be incorporated in gypsum based composites forming part of new lightweight products.
\end{abstract}

\section{Keywords}

Gypsum plaster, waste rubber recovering, mechanical properties, lightweight composite.

\section{Highlights}

- A lightweight composite is obtained with the addition of waste rubber to gypsum

- There is physical compatibility between gypsum and pipe foam insulation waste rubber

- This composite can be part of the core of plasterboards used in construction.

- Mechanical strength decreases with an increase in waste rubber addition

- Samples' flexural strengths with different waste proportions fulfill EN Standards.

\section{Introduction}

Over the past decades, sustainable development has been promoted by a number of EU policies, among these the Europe 2020 Strategy must be highlighted, aiming to transform the EU into knowledgebased, resource efficient and low-carbon economy, and providing a sustainable response to the challenges facing the EU up to 2020.

Moreover, the Directive 2008/98/EC on waste, establishes that the Member States shall take measures to promote high quality recycling by 2020 [1]. In this scenario, new ideas to achieve the targets stated by the Directive are a need. Although in recent years a high percentage of the society has become aware about environmental issues, the targets set out concerning waste recycling and recovery are far away from reality, since a high rate of wastes generated is annually disposed in landfills, contributing therefore to climate change, affecting several ecosystems and human health. 
On the other hand, a good waste management minimizes environmental impacts such as greenhouse gas emissions, promotes efficient use of resources, and provides a new source of recycled materials [2].

The Spanish Law 22/2011 on waste and contaminated soils, transposes the Directive 2008/98/EC on waste, and promotes the minimization of waste disposal in landfill, leading the Nation towards the desired European recycling society [3]. Moreover, three years before, in order to improve the waste management and to encourage the different Public Administrations and stakeholders involved to achieve specific objectives, the current National Waste Plan 2008-2015 (PNIR, Spanish acronym) was launched. The PNIR includes thirteen Specific Waste Plans and provides an analysis of the situation of different waste categories and the measures and environmental targets set for their correct management [4].

In Spain, the manufacturing activity of pipe foam insulation generates an output of scrap material of around 10 per cent by weight of its total production, meaning a high volume of waste due to the low density of the material. Just one manufacturing plant can generate $400 \mathrm{t}$ of this type of waste rubber per year, which if disposed in landfills, represents an important environmental impact. With the objective of minimizing the disposal of this waste in landfills, the research presented in this article aims to study the potential of incorporating different fractions of pipe foam insulation rubber waste in a gypsum based matrix.

Fig. 1 shows the total waste rubber generated in Spain, from 2004 to 2010, in the category "Manufacture of chemical, pharmaceutical, rubber and plastic products" according to the data from the EU statistics web page Eurostat [5].

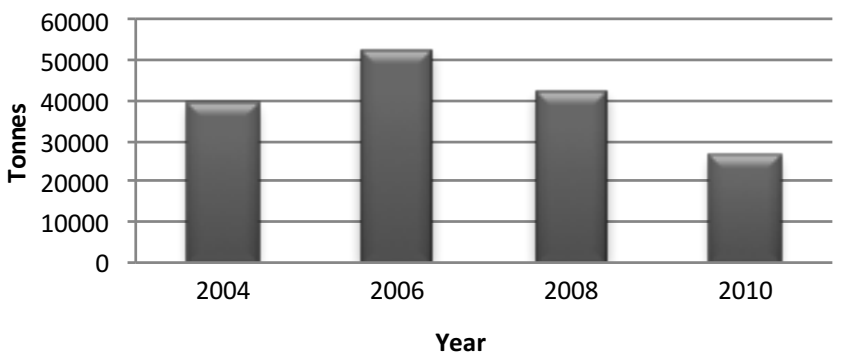

Fig.1. Generation of waste rubber in Spain, in its manufacture process [5]

In particular, the waste rubber studied within this research is classified by the PNIR in the category of "non-hazardous industrial waste" and it is characterized by presenting a low rate of re-use, recycling and other recovering operations.

Previous investigations that assess the incorporation of different types of wastes rubber in composites have been conducted by other researchers. Examples are those that study the addition of waste rubber from used tyres to a concrete, cement mortar or gypsum matrix. In recent years, there has been an extensive progress concerning the management of used tyres, reaching in many EU countries, recovery and recycling levels near to $100 \%$, mainly due to the landfill disposal prohibition stated by the End of life Vehicles Directive [6] and the Directive on the Landfill of Waste [7]. Among others, the following studies can be highlighted:

- Turatsinze et al (2005) tested cement-based mortar incorporating rubber aggregates from recycled worn tyres. [8]

- Del Río et al (2007) studied the use of rubber granulation made from worn tyres in lightened cement mortars. [9]

- Serna et al (2012) analyzed the addition of rubber from recycled tyres to gypsum plaster. [10]

- Rahman et al (2012) studied the fundamental properties of rubber from the waste tyres modified self-compacting concrete. [11]

However, it is important to note that the waste rubber coming from used tyres is completely different to that coming from pipe foam insulation. Waste rubber from worn tyres is mainly composed of styrene- 
butariene, polybutadiene and vulcanized rubber with a density around $390-535 \mathrm{~kg} / \mathrm{m}^{3}$, while the waste subject of this research is a nitrilic and flexible foam rubber with a tiny density, between $45-100 \mathrm{~kg} / \mathrm{m}^{3}$.

Moreover, there are also some previous experiences about adding other types of wastes to a gypsum plaster matrix:

- Hernández-Olivares et al $(1992,1999)$ studied the sisal short fiber and the cork addition [12] [13].

- Oteiza San José and De Villanueva y Domínguez (1993) studied sisal fiber reinforced hemihydrated gypsum as components in low cost housing [14].

- González Madariaga and Lloveras Macía (2008) analyzed gypsum containing expanded polystyrene [15].

- Kim (2009) studied gypsum-rice husk boards [16].

- García Santos (2009) obtained a new construction material by adding EPS beads and short polypropylene fiber to gypsum plaster [17].

In short, after a deep review of the published scientific literature and documentation, no previous experience has been found about the addition of ground rubber coming from pipe foam insulation in composites or any study about its reuse, recycling or other ways of recovery.

In view of the foregoing, the main objective of the research study here presented is to study the physical and mechanical performance of ground waste rubber added to a gypsum-plaster matrix forming part of a new composite material.

\section{Experimental details}

The tests have been conducted in the Construction Materials Laboratory and the Physics Laboratory of the School of Building Engineering, at the Technical University of Madrid (UPM).

The environmental conditions in the Construction Materials Laboratory (where the samples have been produced) were: $25.6{ }^{\circ} \mathrm{C}(298.6 \mathrm{~K})$ of average temperature and $36.3 \%$ of relative air humidity.

\subsection{Materials}

The composite constituents have been:

- Gypsum, a millennial material, traditionally used in building construction. It is at the same time a trendy material due to its exceptional properties as it provides fire protection and contributes to equilibrate humidity and heat peaks in buildings.

To carry out this research work gypsum plaster E-35 has been selected, which is used by some producers to manufacture gypsum plasterboards. According to UNE-EN 13279-1 Standard [18], E-35 plaster is classified as Type A and certified by N mark from AENOR. The main characteristics of gypsum plaster E-35 are shown in Table 1.

Table 1

Plaster main characteristics.

\begin{tabular}{lllll}
\hline E-35 Plaster & & & & \\
\hline $\begin{array}{l}\text { Thermal conductivity } \lambda \\
(\mathrm{W} / \mathrm{m} \cdot \mathrm{K})\end{array}$ & Purity $(\%)$ & $\begin{array}{l}\text { Size } \\
(\mathrm{mm})\end{array}$ & $\begin{array}{l}\text { Flexural Strength } \\
(\mathrm{MPa})\end{array}$ & $\begin{array}{l}\text { water/plaster } \\
(\mathrm{w} / \mathrm{p}) \text { ratio }\end{array}$ \\
\hline 0.30 & $>90$ & $>0.2$ & $>3$ & $0.7-0.8$ \\
\hline
\end{tabular}

- Ground rubber coming from pipe foam insulation, which main objective is to achieve energy savings in buildings. It is a flexible elastomeric insulation material which optimizes the energy performance of heating and plumbing facilities. It is self-extinguishing in contact with fire, nondripping and non-fire conductor. 
As already mentioned, the waste rubber under analysis comes from the material rejected during the production process of pipe foam insulation in a Spanish manufacturing plant, (its main characteristics are shown in Table 2), and it is classified in the European List of Waste (ELW) as 0702 13: Waste Plastic [19]. Table 2

Pipe foam insulation main characteristics.

\begin{tabular}{llll}
\hline Waste rubber & & & \\
\hline $\begin{array}{l}\text { Max. service } \\
\text { temperature }\left({ }^{\circ} \mathrm{C}\right)\end{array}$ & $\begin{array}{l}\text { Thermal conductivity } \\
\lambda_{40{ }^{\circ} \mathrm{C}}(\mathrm{W} / \mathrm{m} \cdot \mathrm{K})\end{array}$ & $\begin{array}{l}\text { Size } \\
(\mathrm{mm})\end{array}$ & $\begin{array}{l}\text { Density } \\
\left(\mathrm{g} / \mathrm{cm}^{3}\right)\end{array}$ \\
\hline+105 & $\leq 0.036$ & $1-25$ & $0.045-0.1$ \\
\hline
\end{tabular}

The initial waste rubber ground size, delivered by the plant, varies from 20 to $25 \mathrm{~mm}$. Subsequently, for the purpose of the research, it has been mechanically shredded in laboratory to sizes from the biggest received of $25 \mathrm{~mm}$ to the smallest one obtained of $1 \mathrm{~mm}$. Afterwards, the shredded waste rubber has been sieved in order to study the following four different sizes: 1-2 mm (A), 2-4 mm (B), 4-6 mm (C) and 20-25 $\mathrm{mm}$ (D) (Fig. 2).
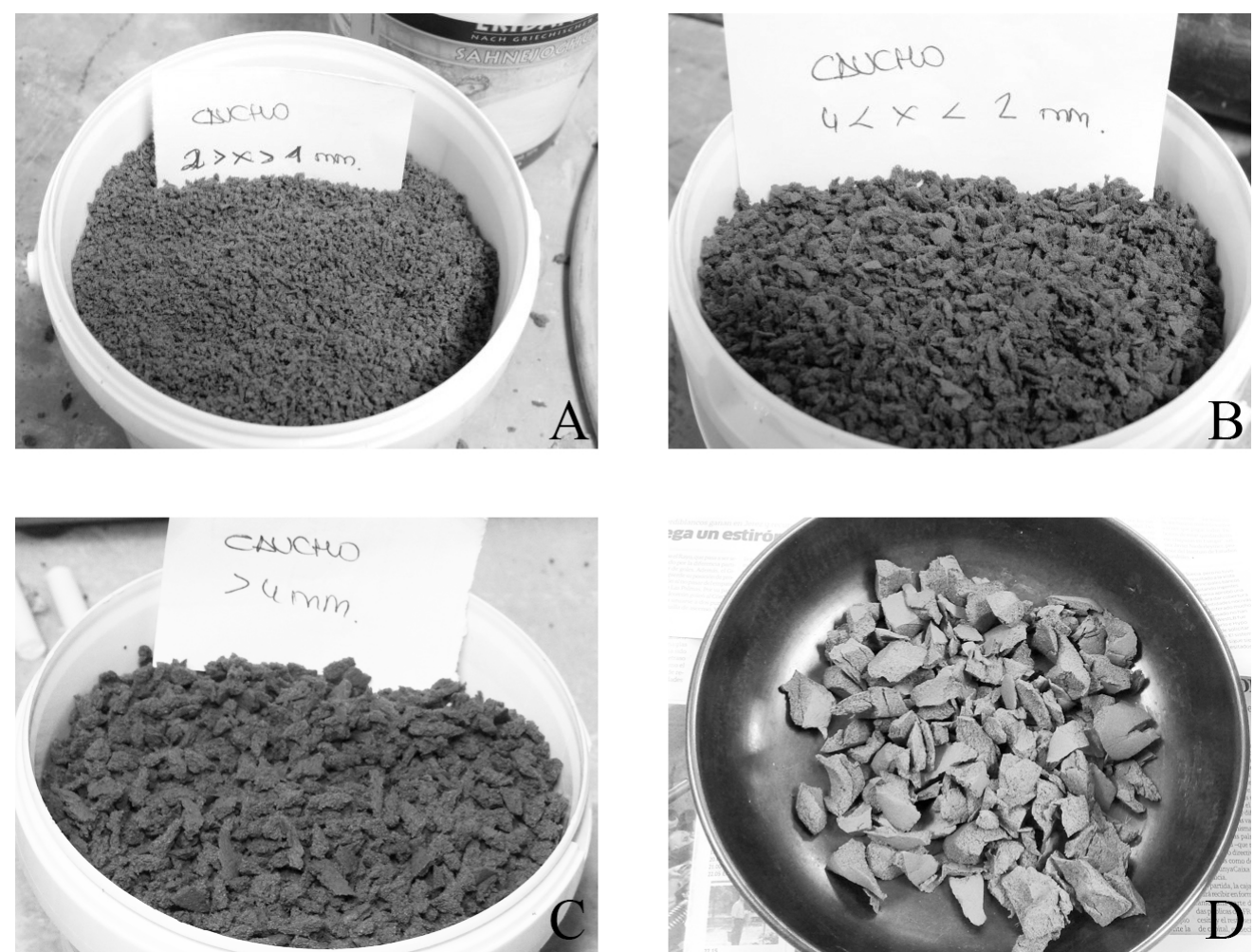

Fig. 2. Different particle sizes studied within this study

2.2 Samples elaboration and methodology.

Several series of samples were analyzed, composed by different sizes of crumb rubber (1-2 mm, 2$4 \mathrm{~mm}, 4-6 \mathrm{~mm}$, and $20-25 \mathrm{~mm})$ with the addition of four rubber percentages by plaster weight $(1.25 \%$; $2.50 \% ; 5.00 \%$ and $7.50 \%$ ) and water/plaster (w/p) ratios of 0.70 and 0.76 . Fig. 3 shows how the ground rubber is distributed inside the samples, obtaining in most of the cases a homogeneous distribution.

Gypsum plaster samples without addition of waste rubber were also elaborated with both 0.70 and $0.76 \mathrm{w} / \mathrm{p}$ ratios, in order to compare the results obtained with the rest of samples produced. From now on these samples are called reference samples.

Series of $40 \mathrm{~mm} \times 40 \mathrm{~mm} \times 160 \mathrm{~mm}$ (three per series) were produced in order to assess the physical and mechanical behavior of the new composite. 
The limit of waste rubber addition accepted by the mixture was $7.50 \%$ by plaster weight. Above this rate the waste volume exceeded the plaster amount, and therefore made it impossible to produce a suitable mixture.

First of all, the waste rubber water absorption capacity was tested.

In order to assess the density of the samples produced, wet weight was recorded after they were unmolded, then they were kept for six days in laboratory atmosphere and later stored for 24 hours in a stove (CENTERM 150 model), at $40 \pm 2{ }^{\circ} \mathrm{C}(313 \pm 279 \mathrm{~K})$, to reach a constant mass and in order to obtain the dry weight value which was also recorded. The following day, the samples were cooled in a desiccator to achieve the room temperature and being subsequently mechanically and physically tested. The reference standard for this process has been the UNE-EN 13279-2.

Shore $\mathrm{C}$ hardness measures were taken according to UNE-EN 102-039-85 [20], and the reference standard for flexural and compressive strength were the UNE-EN 13279-2 using the model Autotest200/10-SW machine.

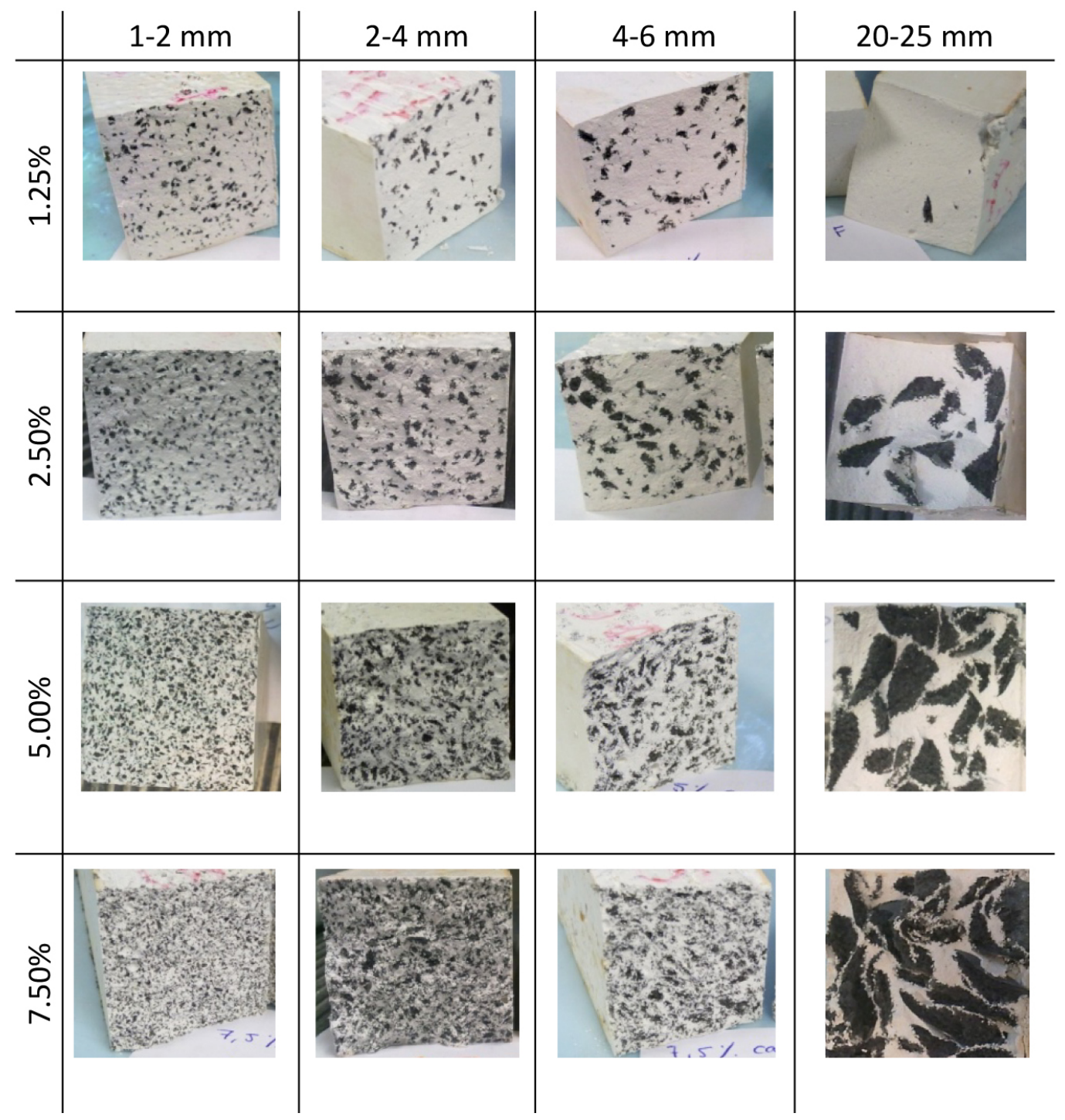

Fig. 3. Different prismatic samples produced.

\section{Results and discussion}

The average results obtained have been summarized in Table 3 and are further detailed in the following subsections.

Table 3 
Test results.

\begin{tabular}{|c|c|c|c|c|c|c|c|c|c|}
\hline \multirow[t]{2}{*}{ Results } & & \multicolumn{2}{|c|}{$1-2 \mathrm{~mm}$} & \multicolumn{2}{|c|}{$2-4 \mathrm{~mm}$} & \multicolumn{2}{|c|}{ 4-6 mm } & \multicolumn{2}{|c|}{$20-25 \mathrm{~mm}$} \\
\hline & & 0.70 & 0.76 & 0.70 & 0.76 & 0.70 & 0.76 & 0.70 & 0.76 \\
\hline \multirow[t]{6}{*}{ Density $\left(\mathrm{g} / \mathrm{cm}^{3}\right)$} & $1.25 \%$ & 1.03 & 0.98 & 1.01 & 0.96 & 1.02 & 0.98 & 0.93 & 0.91 \\
\hline & $2.50 \%$ & 0.99 & 0.95 & 0.98 & 0.93 & 0.99 & 0.95 & 0.86 & 0.79 \\
\hline & $5.00 \%$ & 0.95 & 0.92 & 0.95 & 0.92 & 0.92 & 0.92 & 0.63 & 0.66 \\
\hline & $7.50 \%$ & 0.95 & 0.92 & 0.95 & 0.90 & 0.88 & 0.96 & 0.56 & 0.58 \\
\hline & \multirow{2}{*}{\multicolumn{4}{|c|}{$\begin{array}{l}\text { Reference specimen density } \\
\left(\mathrm{g} / \mathrm{cm}^{3}\right)\end{array}$}} & 0.70 & 1.09 & & & \\
\hline & & & & & 0.76 & 1.04 & & & \\
\hline \multirow{6}{*}{$\begin{array}{l}\text { Shore C hardness } \\
\text { UNE-EN 102-039-85 }\end{array}$} & $1.25 \%$ & 79 & 77 & 82 & 80 & 85 & 81 & 85 & 84 \\
\hline & $2.50 \%$ & 82 & 75 & 82 & 82 & 84 & 82 & 79 & 81 \\
\hline & $5.00 \%$ & 76 & 75 & 77 & 76 & 81 & 73 & 77 & 64 \\
\hline & $7.50 \%$ & 76 & 71 & 75 & 66 & 77 & 77 & 58 & 62 \\
\hline & \multirow{2}{*}{\multicolumn{4}{|c|}{ Reference Shore C hardness }} & 0.70 & 89 & & & \\
\hline & & & & & 0.76 & 84 & & & \\
\hline \multirow{6}{*}{$\begin{array}{l}\text { Flexural strength } \\
\text { (MPa) } \\
\text { UNE-EN 13279-2 }\end{array}$} & $1.25 \%$ & 4.33 & 3.91 & 4.02 & 3.32 & 4.65 & 3.77 & 3.87 & 4.05 \\
\hline & $2.50 \%$ & 4.05 & 3.19 & 3.57 & 2.86 & 3.96 & 2.68 & 2.95 & 2.48 \\
\hline & $5.00 \%$ & 3.25 & 2.57 & 2.82 & 2.78 & 2.49 & 2.31 & 1.60 & 1.35 \\
\hline & $7.50 \%$ & 2.89 & 2.44 & 2.42 & 1.98 & 2.22 & 2.29 & 1.42 & 1.10 \\
\hline & \multirow{2}{*}{\multicolumn{4}{|c|}{$\begin{array}{l}\text { Reference flexural strength } \\
(\mathrm{MPa})\end{array}$}} & 0.70 & 5.97 & & & \\
\hline & & & & & 0.76 & 5.41 & & & \\
\hline \multirow{6}{*}{$\begin{array}{l}\text { Compressive } \\
\text { strength (MPa) } \\
\text { UNE-EN 13279-2 }\end{array}$} & $1.25 \%$ & 9.14 & 7.86 & 9.10 & 7.49 & 10.14 & 8.29 & 7.41 & 7.33 \\
\hline & $2.50 \%$ & 9.01 & 6.00 & 6.88 & 5.79 & 7.03 & 5.46 & 6.03 & 3.91 \\
\hline & $5.00 \%$ & 5.98 & 4.77 & 5.28 & 4.54 & 4.75 & 3.77 & 1.74 & 1.90 \\
\hline & $7.50 \%$ & 4.92 & 4.01 & 4.04 & 3.25 & 3.57 & 3.87 & 1.04 & 0.97 \\
\hline & \multirow{2}{*}{\multicolumn{4}{|c|}{$\begin{array}{l}\text { Reference compressive strength } \\
(\mathrm{MPa})\end{array}$}} & 0.70 & 13.36 & & & \\
\hline & & & & & 0.76 & 11.99 & & & \\
\hline
\end{tabular}

3.1 Water absorption of the ground waste rubber

The ground waste rubber was immersed in water, for both 5 and 30 minutes, noting its initial and final weight. It has been verified that during the first 5 minutes the waste rubber absorbed more than $50 \%$ of its total capacity.

Table 4 shows the waste rubber water absorption results.

Table 4.

Water absorption results.

\begin{tabular}{lcll}
\hline \multicolumn{4}{l}{ Waste water absorption } \\
\hline $\begin{array}{l}\text { Immersion } \\
\text { time }(\mathrm{min})\end{array}$ & Initial weight $(\mathrm{g})$ & $\begin{array}{l}\text { Final } \\
\text { weight }(\mathrm{g})\end{array}$ & Water absorption $(\%)$ \\
\hline 5 & 2,98 & 7,05 & 136,58 \\
\hline 30 & 2,98 & 7,88 & 164,43 \\
\hline
\end{tabular}

When proceeding to the mixture of the three constituents (plaster, waste rubber and waster), despite having most of the water absorbed by the plaster, a small part of the water was also absorbed by the waste rubber causing therefore a reduction of the $\mathrm{w} / \mathrm{p}$ ratio initially considered driving to a quicker setting of the 
mixture. As larger the rubber content is, the w/p ratio is lower, the setting of the plaster will be quicker when producing the samples

\subsection{Density of the composite}

The waste rubber addition to the plaster matrix entails a density decrease in all the elaborated samples, due to the low density of the ground foam rubber (Table 3 ). The values obtained with the addition of 1-2 mm, 2-4 mm and 4-6 mm particle sizes resulted very similar to those of the reference sample, varying between 0.88 and $1.03 \mathrm{~g} / \mathrm{cm}^{3}$, characterized by the low volume of plaster replaced.

Results show that, compared to the reference samples, up to $49 \%$ of density lost is obtained when adding $7.5 \%$ of $20-25 \mathrm{~mm}$ waste rubber particle size with $0.70 \mathrm{w} / \mathrm{p}$ ratio, and a $44 \%$ density lost is obtained in samples with $0.76 \mathrm{w} / \mathrm{p}$ ratio, becoming a much more lightweight composite (See Fig. 4). In this case, the volume of plaster replaced in the sample is bigger.
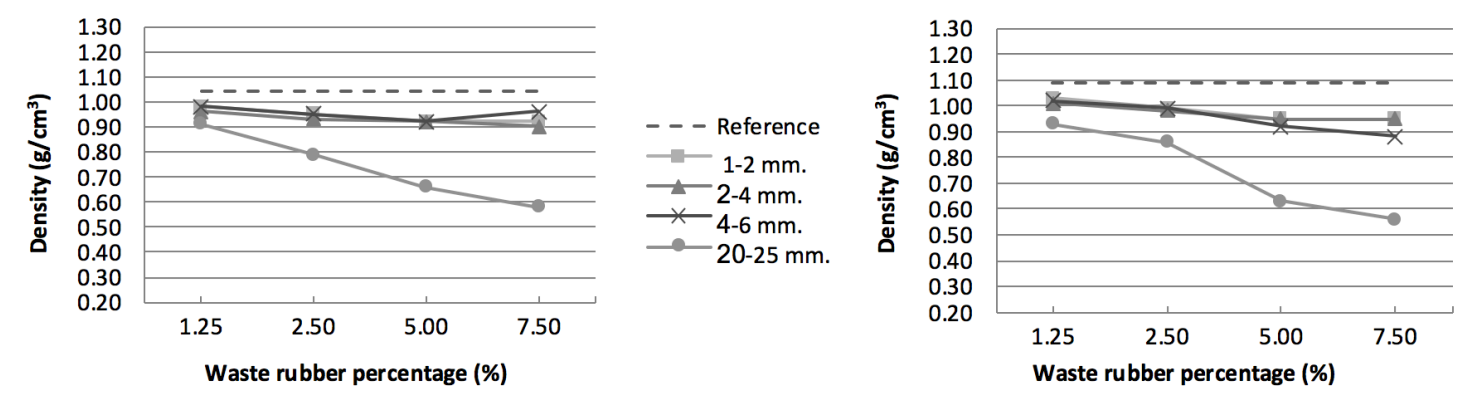

Fig. 4. Density - waste rubber percentage w/p 0.76 (left) and w/p 0.70 (right)

In average, the $0.70 \mathrm{w} / \mathrm{p}$ ratio results, obtained for all the samples, are $2.5 \%$ higher than the $0.76 \mathrm{w} / \mathrm{p}$ ones. This was expected due to the difference in the water content.

\subsection{Shore C hardness}

The Shore $\mathrm{C}$ values recorded in laboratory present a high variability, because of the presence of rubber particles near the samples surface. This is particularly evident for $7.50 \%$ waste content and 20-25 $\mathrm{mm}$ waste rubber size, where most of the surface of the piece is rubber (See Fig. 5).
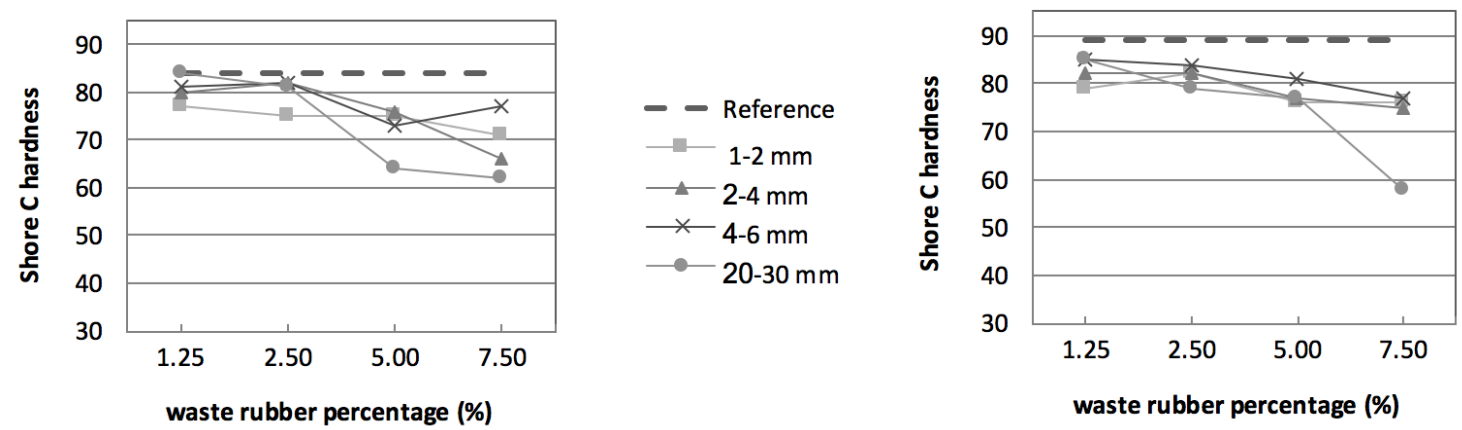

Fig. 5. Shore C hardness - waste rubber percentage w/p 0.76 (left) and w/p 0.70 (right).

\subsection{Flexural strength test}

It can be stated that the waste rubber addition increases the composite plastic period. Once the breaking load is achieved there isn't a division between both sides, remaining strongly joined in most of the cases (Fig. 6). 

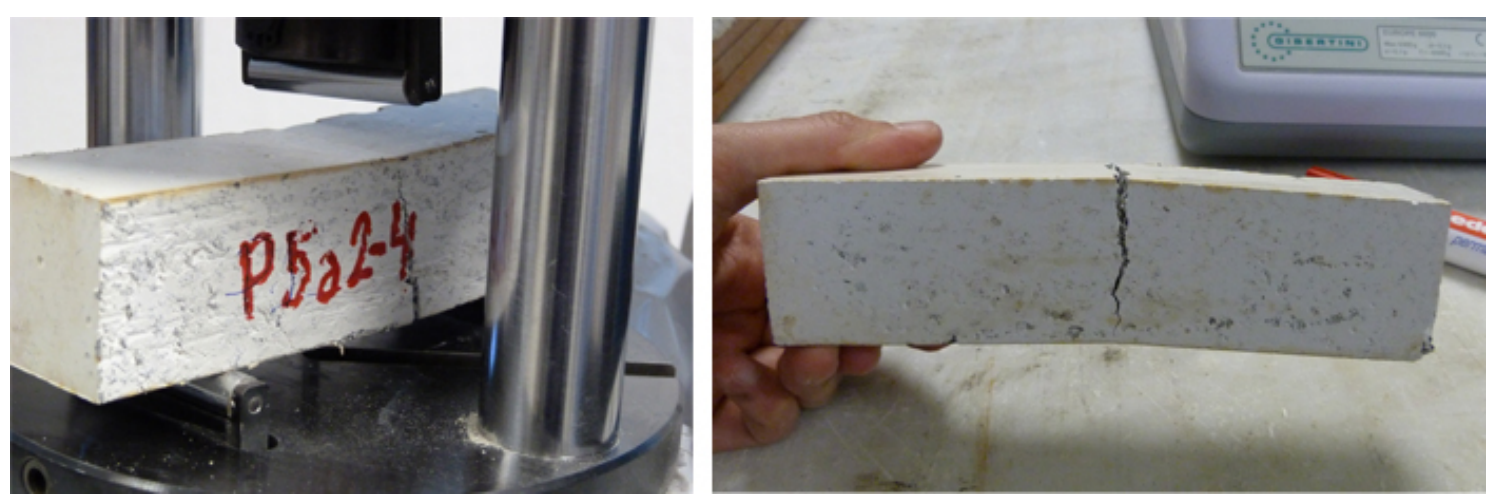

Fig. 6. Rubber-plaster sample after the flexural strength test (2-4mm 5\%)

However, an important strength loss is observed when increasing the rubber addition and as larger its size is (Fig. 7).

Samples containing waste rubber from 1-6 mm kept flexural strength values over 1.98 MPa in every case. However, $20-25 \mathrm{~mm}$ size particles with higher percentages of waste added $(5.00 \%$ and $7.50 \%)$ showed an important strength decrease, suffering an $80 \%$ of strength loss (samples with 7,50\% rubber and $0,76 \mathrm{w} / \mathrm{p}$.

All the obtained results fulfilled the UNE-EN 13279 standard, which defines $1 \mathrm{MPa}$ as the minimum value accepted.
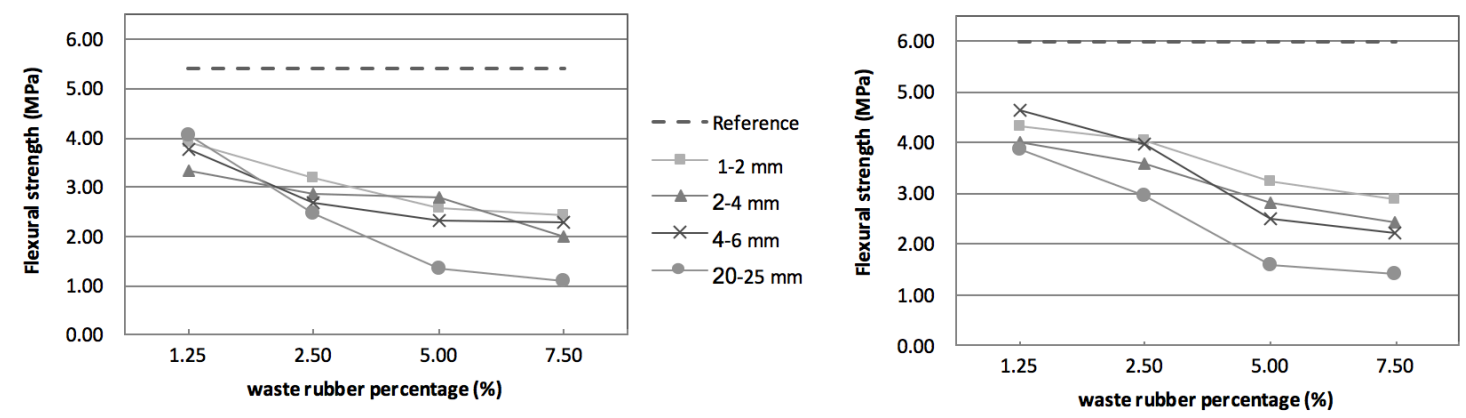

Fig. 7. Flexural strength - waste rubber addition w/p 0.76 (left) and w/p 0.70 (right).

Density and mechanical strength are directly related, decreasing both features as a higher percentage of waste rubber ground is added. An example is shown in Fig.8, where the 4-6 $\mathrm{mm}$ series flexural strength and their density are compared.

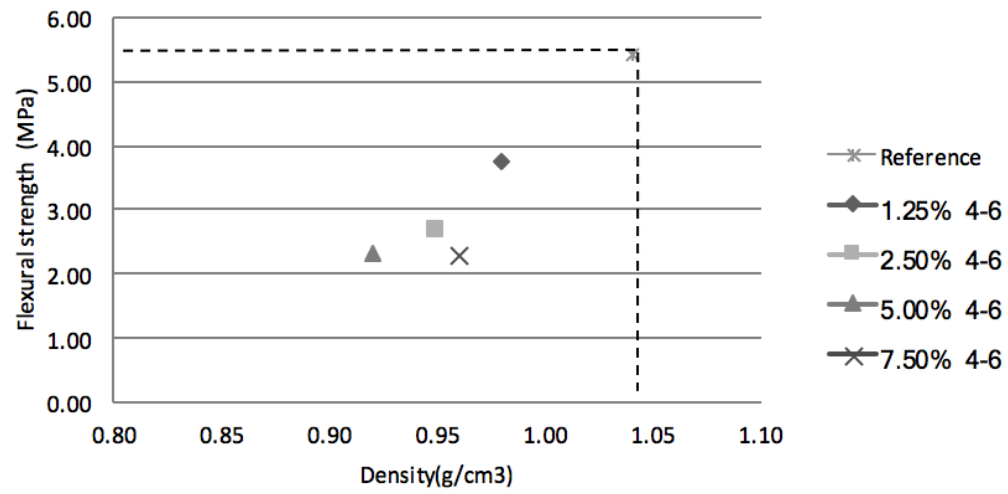

Fig. 8. Flexural strength - density w/p 0.76 . 
Once the breaking load is reached, the different fragments are still linked, allowing the material being deformed after exceeding its breaking load (Fig 9).

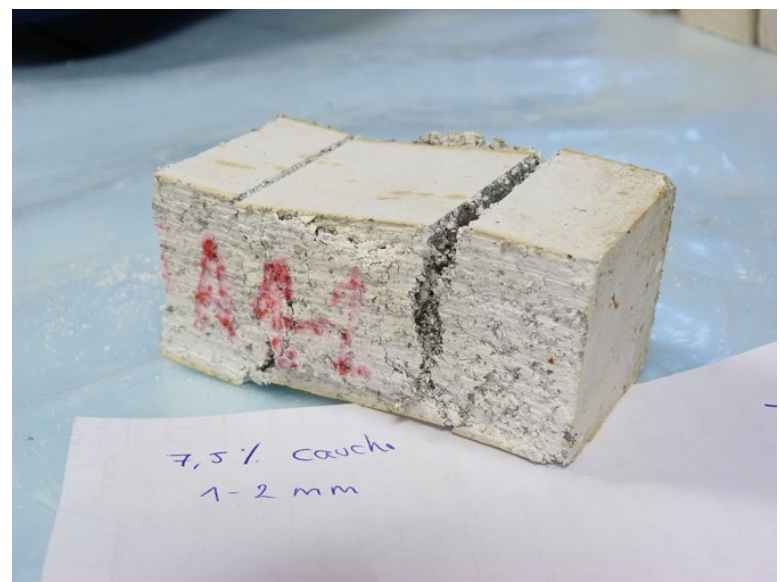

Fig. 9. Sample after exceeding its breaking load.

The composite material compressive strength resulted much smaller than the reference sample (see Fig. 10), not fulfilling the UNE-EN 13279 standard requirements (2MPa) from the composite with 20-25 size rubber for both, $5.00 \%$ and $7.50 \%$ waste addition.
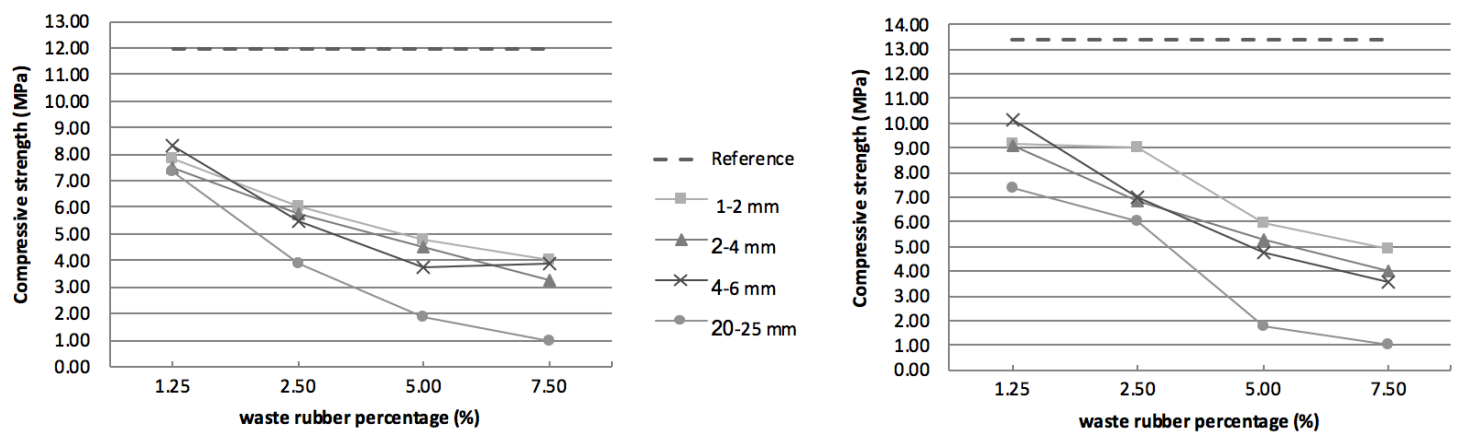

Fig. 10. Compressive strength - waste rubber content w/p 0.76 (left) and w/p 0.70 (right).

\section{Conclusions}

In this study, the physical and mechanical properties of a new lightweight composite material prepared with waste foam ground rubber as addition in gypsum-plaster matrix were investigated and discussed.

Based on the results of this study, the following conclusions can be drawn:

1. The maximum waste weight percentage addition accepted by the mixture is $7.50 \%$. Higher content of waste rubber exceeds the volume of plaster and thus makes it difficult to produce the specimen.

2. There is a good compatibility between waste rubber coming from pipe foam insulation and the plaster matrix. Despite the low density waste particles present, the ground rubber is distributed in a proper way inside the samples: they don't float in the mixture and therefore a homogenous paste is obtained.

3. The plaster-rubber composite obtained is a lightweight construction material: up to $49 \%$ density reduction is reached compared to the reference samples.

4. Mechanical strength decreases with an increase in waste rubber addition, highlighting a decrease when adding larger particle sizes. However, all the flexural strength values obtained 
reached the UNE-EN 13279 requirements. On the other hand, samples with $5.00 \%$ and $7.50 \%$ waste rubber additions and 20-25 mm particle sizes didn't meet the compressive strength requirements.

5. Between the different waste rubber particle sizes studied, size 4-6 mm resulted the most suitable to be used as addition in the new composite material without compromising the composite mechanical behavior. Moreover, the mechanical grinding of the waste rubber is minimized as larger the particle size is, and thus less specialized equipment is required.

6. The incorporation of waste foam rubber in the new composite material will help to reduce the huge volumes of scrap material accumulated in landfills and therefore minimize both social and environmental representing costs.

In view of the results, this ground foam rubber is suitable for its incorporation in gypsum based products. As an example, it could be embedded in the core of plasterboards, obtaining a new lightweight product for building construction, hard in surface and easy to handle and to install. This investigation provides the basis for future studies aiming to analyze other characteristics of the new composite, such as thermal and fire behavior, when used as construction material.

\section{Acknowledgement}

This research work was carried out within the Postgraduate Programme "Technological Innovation in Building", in the School of Building Engineering of the Technical University of Madrid. The authors would like to thank the Construction Materials and Physics laboratory workers for their assistance.

\section{References}

[1] Directive 2008/98/EC of the European Parliament and of the Council of 19 November 2008 on waste and repealing certain Directives. Official Journal of the European Union. 22th November 2008. L312.

[2] Communication from the Commission to the European Parliament, the Council, the European Economic and Social Committee and the Committee of the Regions. Rio +20: towards the green economy and better governance, 20th June 2011. COM (2011) 263 final.

[3] Spain. Ley 22/2011, de 28 de julio, de residuos y suelos contaminados. Boletín Oficial del Estado, 29 de julio de 2011, núm. 181, p. 85650.

[4] Spain. Plan Nacional Integrado de Residuos (The Integrated National Waste Plan) 2008-2015 (PNIR). Boletín Oficial del Estado, 26 de febrero de 2009, núm. 49, p. 19893.

[5] Eurostat, 2012. European Communities. Statistics on focus. Available from:

$<$ http://appsso.eurostat.ec.europa.eu/nui/show.do> Last accessed: 20/11/2012

[6] Directive 2000/53/EC of the European Parliament and of the Council of 18 September 2000 on end-of life vehicles. Official Journal of the European Union. 21th October 2000. L269.

[7] Council Directive 1999/31/EC of 26 April 1999 on the landfill of waste. Official Journal of the European Union. 16th July 1999. L182.

[8] Turatsinze A., Bonnet S., Granju J.-L. "Mechanical characterisation of cement-based mortar incorporating rubber aggregates from recycled worn tyres". Building and environment, 40 (2005). p. 221226.

[9] Del Río Merino, M., Santa Cruz Astorqui J., Gónzalez Cortina M. Viability analysis and constructive applications of lightened mortar (rubber cement mortar). Construction and Building Materials, , $\mathrm{n}^{\mathrm{o}} 21$ (2007) p. $1785-1791$.

[10] Serna A., Del Río, M., Gabriel Palomo J., González M. "Improvement of gypsum plaster strain capacity by the addition of rubber particles from recycled tyres". Construction and Building Materials, 35 (2012). p. 633-641.

[11] Rahman M., Usman M., Al-Ghalib A., "Fundamental properties of rubber modified self-compacting concrete (RMSCC)". Construction and Building Materials, 36 (2012). P 630-637.

[12] Hernández-Olivares F., Oteiza I, De Villanueva L. Experimental analysis of toughness and modulus of rupture increase of sisal short fiber reinforced hemihydrated gypsum. Composite Structures, Vol. 22. nº. 3. (1992) p. 123-137. [11] 
[13] Hernández-Olivares, F., Bollati, M.R., Del Rio, M., Parga-Landa, B. (1999) Development of corkgypsum Composites for building applications. Construction and Building Materials, 13 pp. 179-186.

[14] Oteiza San José, I., Villanueva y Domínguez, 1. "Study of the behaviour of sisal fiber reinforced hemihydrated gypsum as components in low cost housing". Informes de la Construcción, vol. 45, no 425 426. (1993). Tesis Doctoral.

[15] González Madariaga, F.J., Lloveras Macia, J. "EPS (expanded poliestyrene) recycled bends mixed with plaster or stucco, some applications in building industry". Informes de la Construcción, 60, (2008) p. 35-43. ISSN: 0020-0883.

[16] Kim, S. (2009) Incombustibility, physico-mechanical properties and TVOC emission behavior of the gypsum-rice husk boards for wall and ceiling materials for construction. Industrial Crops and Products, 29. p. 381-387.

[17] García Santos, A. "PPF-reinforced, EPS-lightened gypsum plaster". Materiales de Construcción, vol. 59, 293. (2009) p. 105-124.

[18] AENOR. Yesos de construcción y conglomerantes a base de yeso para la construcción. Parte 1: Definiciones y especificaciones. UNE-EN 13279-1. Madrid: AENOR, 2009.

[19] European List of Waste. Commission Decision 2000/532/EC, 3rd May 2000. Official Journal of the European Communities, 6th September 2000. L226/4.

[20]AENOR. Yesos y escayolas de construcción, Determinación de la Dureza Shore C, y de la dureza Brinell. UNE-EN 102-039-85. Madrid: AENOR, 1985. 


\section{List of Figure Captions}

Fig. 1. Generation of waste rubber in Spain, in its manufacture process (Eurostat, 2012)

Fig. 2. Different particle sizes studied within this study

Fig.3. Different prismatic samples produced.

Fig. 4. Density - Waste Rubber percentage w/p 0,76 (left) and w/p 0.70 (right)

Fig. 5 Shore C hardness - Waste Rubber percentage w/p 0,76 (left) and w/p 0.70 (right)

Fig. 6. Rubber-plaster sample after the flexural strength test (2-4 mm 5\%)

Fig. 7. Flexural strength - waste rubber addition w/p 0,76 (left) and w/p 0.70 (right)

Fig. 8. Flexural strength - density w/p 0.76

Fig. 9. Sample after exceeding its breaking load.

Fig. 10. Compressive strength - waste rubber content w/p 0,76 (left) and w/p 0.70 (right)

\section{List of Table Captions}

Table 1. Plaster main characteristics.

Table 2. Pipe foam insulation main characteristics.

Table 3. Test results

Table 4. Water absorption results 